\title{
Impact of Barrier Breaching on Wetland Ecosystems under the Influence of Storm Surge, Sea-Level Rise and Freshwater Discharge
}

\author{
Xiaorong $\mathrm{Li}^{1} \cdot$ Nicoletta Leonardi ${ }^{1} \cdot$ Andrew J. Plater ${ }^{1}$ \\ Received: 30 May 2019 / Accepted: 27 August 2019 / Published online: 20 October 2019 \\ (C) The Author(s) 2019
}

\begin{abstract}
Coastal wetland ecosystems and biodiversity are susceptible to changes in salinity brought about by the local effects of climate change, meteorological extremes, coastal evolution and human intervention. This study investigates changes in the salinity of surface water and the associated impacts on back-barrier wetlands as a result of breaching of a barrier beach and under the compound action of different surge heights, accelerated sea-level rise (SLR), river discharge and rainfall. We show that barrier breaching can have significant effects in terms of vegetation die-back even without the occurrence of large storm surges or in the absence of SLR, and that rainfall alone is unlikely to be sufficient to mitigate increased salinity due to direct tidal flushing. Results demonstrate that an increase in sea level corresponding to the RCP8.5 scenario for year 2100 causes a greater impact in terms of reedbed loss than storm surges up to $2 \mathrm{~m}$ with no SLR. In mitigation of the consequent changes in wetland ecology, regulation of relatively small and continuous river discharge can be regarded as a strategy for the management of coastal back-barrier wetland habitats and for the maintenance of brackish ecosystems. As such, this study provides a tool for scoping the potential impacts of storms, climate change and alternative management strategies on existing wetland habitats and species.
\end{abstract}

Keywords Wetland ecosystem $\cdot$ Barrier breach $\cdot$ Climate change $\cdot$ Accelerated sea level rise $\cdot$ Storm surge $\cdot$ Freshwater discharge $\cdot$ Wetland loss $\cdot$ Reedbeds $\cdot$ Mitigation strategies $\cdot$ Coastal wetland management strategies

\section{Introduction}

Wetlands are commonly found along low energy coastal environments, and provide important ecosystem services and economic benefits (e.g., Gedan et al. 2009, 2011; Ndebele and Forgie 2017; Li et al. 2018). The resilience of these coastal ecosystems under a changing climate is uncertain, as they are under pressure from accelerated sea-level rise (SLR) and

Electronic supplementary material The online version of this article (https://doi.org/10.1007/s13157-019-01219-x) contains supplementary material, which is available to authorized users.

Xiaorong Li

xiaorongli.912@gmail.com; lixr@liverpool.ac.uk

1 Department of Geography and Planning, School of Environmental Sciences, University of Liverpool, Roxby Building, Chatham Street, Liverpool L69 7ZT, UK changes in the frequency and/or magnitude of storms (e.g. Leonardi and Fagherazzi 2014; Chambers et al. 2016; Leonardi et al. 2017). Indeed, a recent study shows a high probability for salt marsh retreat under projected future sealevel rise (Horton et al. 2018), whilst Leonardi et al. (2017) stresses the critical importance of storms in determining the long-term response. Depending on the region, and various environmental factors, predicted wetland loss by the end of the century has been estimated to be around 0 to $50 \%$ (Gilman et al. 2006; McFadden et al. 2007; Alongi 2008; Kirwan et al. 2016). This is likely to be an underestimate given that sealevel rise over this century could double previous projections (Grinsted et al. 2015; Bamber et al. 2019). Further, financial resource limitations may require a move from 'hold the line' to 'no active intervention' or 'managed realignment' options (Esteves and Williams 2017) for coastal management which can potentially impact back-barrier wetlands and habitats (Rupp-Armstrong and Nicholls 2007; Friess et al. 2014; Brady and Boda 2017). Notable managed realignment 
examples in the UK include Tollesbury (Garbutt et al. 2006), Freiston (Friess et al. 2014), Hesketh Marsh (Tovey et al. 2009), and Medmerry (Dale et al. 2017, 2018).

Coastal wetlands can be significantly affected by increases in water levels through the following three major ways: increased inundation period, increased surface erosion and saltwater intrusion (Blankespoor et al. 2014). Although increased flooding can potentially aid the survival of wetlands through promoting sedimentation and biomass growth (e.g. Kirwan et al. 2016; Schieder et al. 2018), changes in the extent and duration of marine inundation can cause die-back of the less salt tolerant species, and landward migration of vegetation types that are more resilient to increased hydroperiod (Donnelly and Bertness 2001). Changes in high water levels as a consequence of storm surges or SLR are thus linked to potential changes in biodiversity (e.g. Field et al. 2016; Kirwan et al. 2016). Indeed, increased salinity due to higher sea levels has been causing land degradation in many coastal areas worldwide, compromising food production and freshwater availability (e.g. Milliman et al. 1989; Craft et al. 2009; Lovelock et al. 2015). In the UK, for instance, land degradation as a consequence of storm surges is becoming a pressing issue. The Environment Agency has estimated that 432,000 ha of agricultural land with a capital value of over $£ 132$ billion are potentially at risk from surge-driven coastal flooding (Halcrow Group Ltd et al. 2001).

Unlike SLR, which is a gradual and long-lasting change in water levels, storm events are more unpredictable and shortlived, and changes caused by storm events can be more dramatic in the short term due to their high-energy nature (e.g. Gable et al. 1990; Walker 1991; Orr and Ogden 1992; Duever et al. 1994). Apart from damage associated with physical stresses (e.g. uprooting), storms can increase the salinity of inland water, hence causing changes in physicochemical properties of wetland soil; the combination of which will then alter the metabolic functions responsible for plant productivity (DeLaune et al. 1987; Michener et al. 1997; McKee et al. 2016).

By regulating their respiration rate, plants are generally able to adjust themselves to soil conditions, or influence soil conditions in their favour (Sternberg et al. 2007). For instance, plants that have low salinity tolerance can down-regulate evapotranspiration during dry season to maintain low soil salinity. Therefore, a small disturbance that changes the soil conditions by just a small amount can be offset through adaptation by the local vegetation. For a disturbance to cause vegetation die-back or a regime shift, the event has to cause changes in environmental conditions that exceed certain threshold criteria in terms of strength and/or duration of the impact on the system (Jiang et al. 2014). When the severity of the event, e.g. surge height or duration of flooding, is such that threshold criteria are exceeded, a shift in nature, size and distribution of plant communities across coastal wetlands is likely to occur (DeLaune et al. 1987; Teh et al. 2008; Chambers et al. 2016).

Storm events can also cause morphological changes along the coastline which can potentially further exacerbate stressors connected to increased salinity. For instance, processes such as chronic coastal erosion, the breaching of sand dunes and barrier beaches due to over-wash, or the degradation of coastal protection structures will cause a landward migration of the flood limit, enhancing the risk for inland ecosystems. This is especially important for those cases where management strategies follow the 'no active intervention' approach, and for which newly-formed breaching or erosion are a long-lasting condition (Rangel-Buitrago et al. 2018). Indeed, this is also relevant to sites where managed realignment is a likely future option for coastal management, and where the reestablishment of perimarine wetlands has the potential to contribute to sustainable and diverse coastal economies (Plater and Kirby 2006).

This research models potential changes in the salinity of surface water in the back-barrier, brackish wetlands of RSPB Minsmere Nature Reserve (see Study Area), as a case study, in response to combinations of SLR, coastal storms and freshwater inflow following breaching of the barrier beach. Here, we focus on the salinity of the standing water 'post-breach', as determined by tidal rise and fall through the breach, tributary river discharge and local rainfall but excluding the influence of groundwater input and seawater seepage through the coastal barrier. Attention is given to the exceedance of threshold salinity criteria necessary for local vegetation die-back.

\section{Study Area}

The Minsmere Nature Reserve, located on the coastline of Eastern England, UK (Fig. 1), is a site of international significance for the richness of its coastal wetlands. It supports a mix of coastal habitats including intertidal salt marshes, tidal flats and sand dunes (EA 2009). The reserve is a low-lying area with four national conservation priorities: reedbeds (mainly Phragmites australis, established in most of the area north to the Minsmere New Cut), lowland wet grassland (prevalent in the area south of the New Cut where the ground is higher), shingle vegetation and lowland heath. The reserve provides natural habitats for a wide range of wildlife species, such as marsh harriers, Dartford warblers, bitterns, otters, water voles, red deer etc. In addition to the importance related to ecological services, this part of the coastline also hosts nationally important energy infrastructure in the shape of the Sizewell nuclear power station complex, which has been identified as a site for the next generation of nuclear new build. The area thus represents an excellent test case that is representative of other back-barrier wetland sites of national and international significance, particularly in addressing management 
Fig. 1 Geographic location of the case study site - RSPB

Minsmere. The inset shows the geographical coverage of a larger scale model from which the open boundary data is extracted.

Figure also shows terrain height of the site with respect to mean sea level. Labelled points represent locations where modelled surface water salinity is sampled for discussion associated with Figs. S1-4. Along the New Cut, $\mathrm{c} 1$ is located at the barrier breach; $\mathrm{c} 2$ is $1.5 \mathrm{~km}$ away from the breach; c 3 is $2.7 \mathrm{~km}$ away from the breach; and $\mathrm{c} 4$ is $3.7 \mathrm{~km}$ away from the breach. Locations on the northern and southern sides of the New Cut are labelled n1, n2 and $\mathrm{s} 1, \mathrm{~s} 2$ respectively

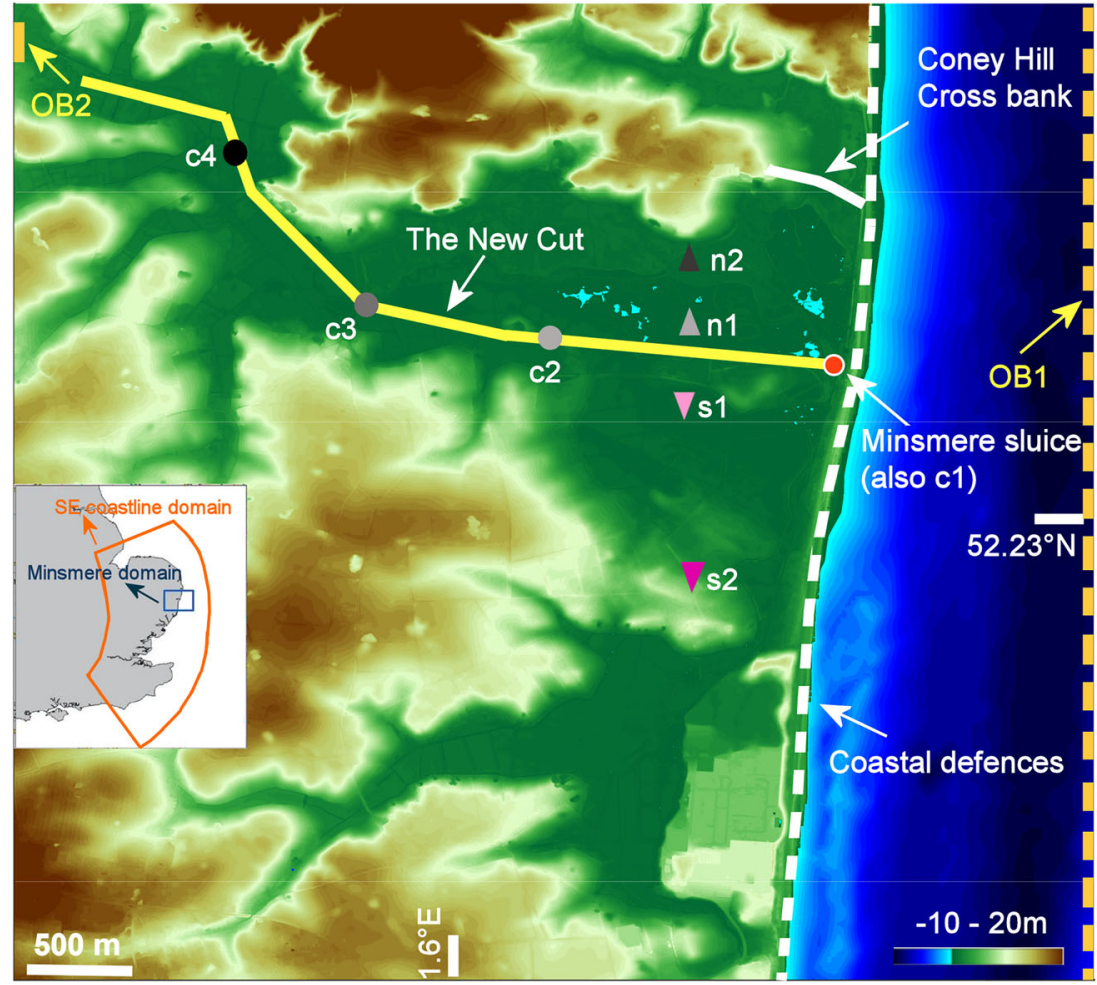

priorities that are set in the context of national infrastructure and habitat action plans, and international frameworks for the conservation of rare and protected species and for the maintenance of biodiversity and ecosystem services. In this respect, Minsmere Reserve is part of the Minsmere-Walberswick Heaths and Marshes Site of Special Scientific Interest (SSSI), Special Area of Conservation (SAC), Special Protection Area (SPA) and Ramsar site. The site is also included in the areas covered by the Suffolk Heritage Coast and the Suffolk Coast and Heaths Area of Outstanding Natural Beauty (AONB).

At Minsmere, the present sea defences include a line of natural and modified sand dunes and sand and gravel ridges spanning the coastline (Fig. 1). The dunes and barrier beach, which are formed of sands and gravels transported alongshore from erosion of the Pliocene and Pleistocene cliffs further north (Brooks et al. 2012), overlie a sequence of unconsolidated Holocene and early Pleistocene sediments that extend beneath the Minsmere wetland (Hamilton et al. 2019). The general character of the coastline has been one of southward sediment transport alongside landward recession due to postglacial sea-level rise, although recent work has shown little evidence of regionally coherent forcing at either centennial (post-1880s) or intra-decadal (post-1990s) timescales (Burningham and French 2017). Prior to the early Middle Ages, the study area was an open estuary formed as a result of early to mid-Holocene flooding of low level river valleys but was cut off from the sea and enclosed by a coastal barrier in the eighteenth century (Pye and Blott 2006). A secondary clay embankment also runs along the back of the dunes in the northern part of the study site (EA 2009; Prime et al. 2015). According to the UK Environment Agency (EA), the longterm stability of these defences is significantly threated by coastal erosion processes, particularly to the north of the RSPB Reserve. For instance, the northern end of the defences was breached due to tidal surges in November 2006 and 2007 , leading to flooding of the area between the dunes and the secondary clay embankment (EA 2009). Hence, a cross bank (Coney Hill Cross Bank in Fig. 1) was built to isolate the northern part of the site from any flooding from the sea. Within the wetland area, a complex network of ditches has been created and maintained to manage water levels through controlled drainage by a manual sluice located midway along the coast (Fig. 1). However, given the projected SLR and costs associated with the maintenance of the sluice and the barrier beach, sustained management of freshwater habitats in Minsmere is not a sustainable long-term option (Pye and Blott 2006). Indeed, the Shoreline Management Plan priorities for the 20, 50 and 100 years epochs are currently identified as 'managed realignment', with the exception of the short section of barrier beach are the north of the site which has a 'no active intervention' policy in place for the 100 year epoch (see Sizewell case study at: https://arcoes-dst.liverpool.ac.uk/).

Managed realignment of the Minsmere shoreline will have significant impacts on the freshwater reedbed environments that currently characterize much of this back-barrier wetland. 
Research has previously established the tolerance of P. australis to salinity (e.g. Ranwell 1964; Roman et al. 1984; Matoh et al. 1988; Robbins et al. 1991; Hellings and Gallagher 1992). It has been found that the tolerance varies depending on the location and growth stage of the plant. For example, while adult plants of the high salinity tolerant US clone can survive at salinities near $65 \mathrm{psu}$, the juvenile plants may die at 35 psu (Engloner 2009). On the other hand, the salt tolerance of $P$. australis in Europe has been found to vary between 5 and $25 \mathrm{psu}$. In the current investigation, following Lissner and Schierup (1997) and Hellings and Gallagher (1992), we assume a die-back of $P$. australis when salinity is above 22.5 psu for a continuous period of 42 days. Consequently, this modelling approach for scoping the potential impacts of barrier breaching on reedbed habitats, whether an intended consequence of management or an unintended result of climate change and/or storms, provides important information for shaping present actions and future decisions regarding the site.

\section{Model Set-up}

With a single breach located in the barrier beach, the study area takes the form of an estuary that features shallow water depth and two-dimensional horizontal circulation and mixing (e.g. hydrodynamic class E estuary in Hume et al. 2007). Here, the shallow water depth enhances the importance of wind-driven mixing, hence limiting the development of stratification through the water column. The two-dimensional (2DH) mode of the numerical model Delft3D (Delft Hydraulics 2014) was therefore used to compute the hydrodynamics and salinity of the Minsmere wetlands. The calculation of salinity is based on the classic advection-diffusion equation (Delft Hydraulics 2014). The computational domain and terrain height with respect to mean sea level for the study area are presented in Fig. 1. The terrain height of the model is obtained from the combination of two datasets: bathymetric data downloaded from EDINA DIGIMAP for the open sea and LiDAR data (DTM Composite England $2 \mathrm{~m}$; tile references are given in the supplementary material) provided by the Environment Agency for the wetland regions. Vertical Offshore Reference Frame (VORF) corrections provided by the UK Hydrographic Office have been applied to adjust these two datasets to Mean Sea Level (MSL). Resolution of the model grid varies from $30 \mathrm{~m}$ in the nearshore to $10 \mathrm{~m}$ in the wetland. The model has two open boundaries: the east boundary (OB1 in Fig. 1) is placed $\sim 1.2 \mathrm{~km}$ offshore in the open sea and the west boundary (OB2 in Fig. 1) is located $\sim 4.0 \mathrm{~km}$ inland. The east boundary is driven by data extracted from a calibrated larger scale model (Leonardi and Plater 2017) covering the coastline of South East England (see larger model domain denoted in Fig. 1 inset). Validation of the model described herein, however, is not carried out due to lack of available data.

An input of freshwater discharge ranging from 3 to $9 \mathrm{~m}^{3} / \mathrm{s}$ has been prescribed for the main drainage channel, the New Cut, which terminates at the sluice through OB2. Model runs have been carried out for idealized test cases with the sluice being breached (either naturally or artificially), i.e. the height of the ridge at the sluice has been lowered to match that of the surrounding areas. The width of the breach has been set equal to the width of the sluice. In this case, the breach morphology is neither created nor evolved by the storm surge. The breach has been located at the sluice as it is the focal point of the drainage network and a breach at this location is expected to maximize the landward intrusion of marine water and, thus, represents the worst case scenarios in terms of the areal extent of the zone affected by increased salinity.

Several scenario-based simulations have been conducted which include one SLR and four simplified storm surges scenarios. For the SLR and each storm surge scenario, three idealized freshwater discharge cases and one rainfall case are run. In the SLR scenario, the water levels have been raised by $0.9 \mathrm{~m}$ according to the RCP8.5 projection for year 2100 (Fig. 2a) (Grinsted et al. 2015). The four storm surge scenarios, $0 \mathrm{~m}, 1 \mathrm{~m}, 2 \mathrm{~m}$ and $3 \mathrm{~m}$, are simulated by imposing half of a sinusoidal wave to the tidal levels of the corresponding period (Fig. 2a). The exceedance probabilities of the abovementioned idealized surges are $100 \%, 4 \%, 0.1 \%$ and $<$ $0.01 \%$, respectively (Source: the "Coastal Design Sea Levels - Coastal Flood Boundary Extreme Sea Levels" dataset by the Environment Agency). The duration of the storm is set equal to three tidal cycles with the peak of the sinusoidal wave in synchronization with high tide to maximize the increase in water levels (Lyddon et al. 2018). Three idealized freshwater discharge values are considered: 0,3 and $9 \mathrm{~m}^{3} / \mathrm{s}$. For the rainfall test cases, historical daily precipitation data provided by the Centre for Ecology \& Hydrology (CEH), UK (Fig. 2b) are applied. The above-mentioned simulations are run for two months to ensure results of full 42 days in addition to the initiation of the models and the duration of the surges.

\section{Results}

\section{Spatial Distribution of Surface Water Salinity}

Salinity of the wetland surface water for the four storm surge scenarios without freshwater input is given in Fig. 3, with Fig. 3a-d showing salinity at the end of the surge and Fig. $3 e-h$ showing salinity 42 days from the end of the surge. For the immediate after-storm period, the affected area in terms of surface water salinity increases as surge height increases. When the surge height is $3 \mathrm{~m}$, the northern end of the coastal defences is overtopped, leading to flooding of the area north of 
Fig. 2 a Water levels imposed on the east open boundary for $0 \mathrm{~m}$, $1 \mathrm{~m}, 2 \mathrm{~m}$ and $3 \mathrm{~m}$ storm surge scenarios; b Historical daily rainfall
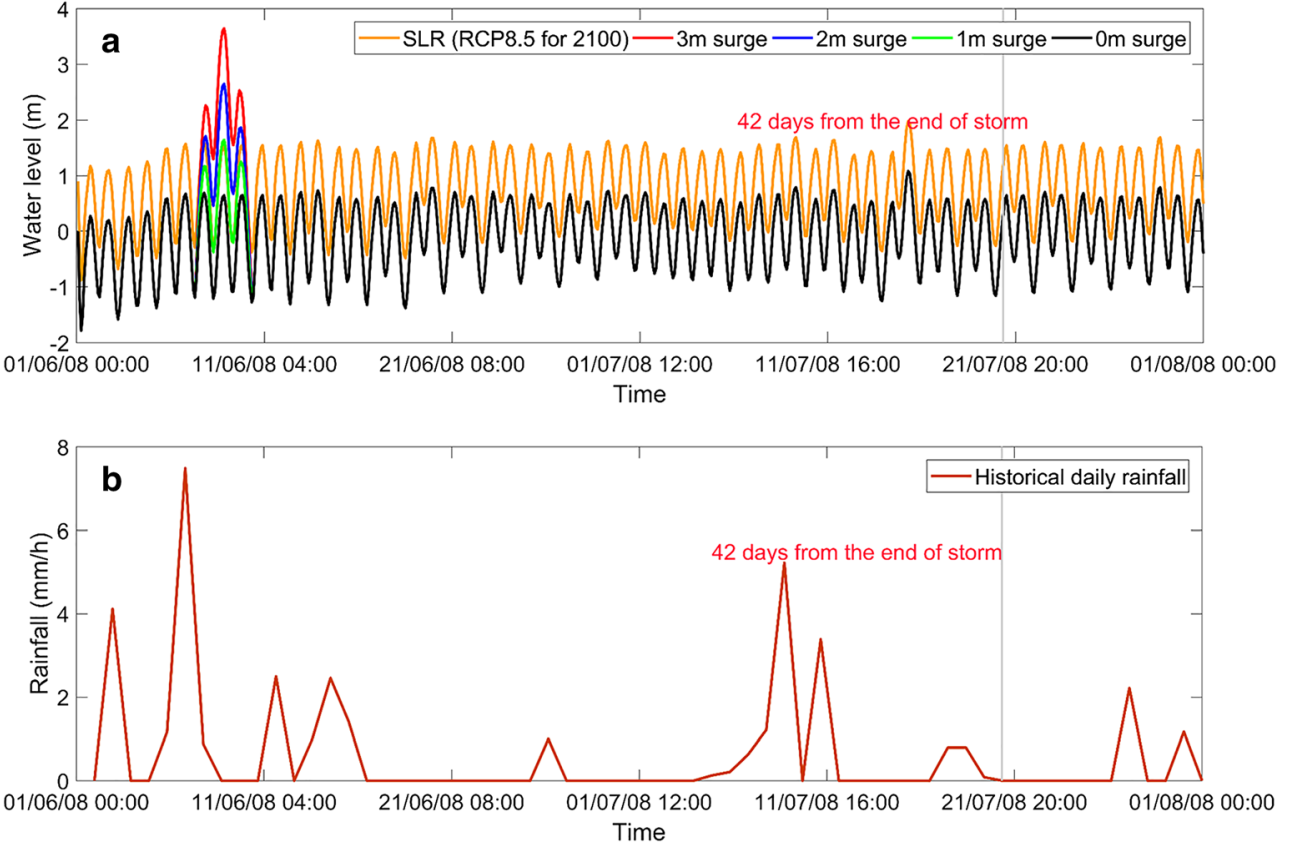

the Coney Hill cross bank (Fig. 3d and h). The exchange of water between inland and seaward areas through the breached sluice is always well pronounced; saline water invades the wetland even without surge ( $0 \mathrm{~m}$ surge scenario). After 42 days, without any source of freshwater being inputted, salinity has diffused across much broader areas and the area affected by surges of different heights becomes comparable.

To investigate impacts of freshwater discharge and rainfall on surface water salinity, two freshwater discharges (3 and 9 $\mathrm{m}^{3} / \mathrm{s}$ ) as well as a historical rainfall record were applied to each surge scenario. Salinity values across the wetland for the scenarios in the immediate aftermath of the storms and after 42 days post-storm are given in Figs. 4, 5 and 6. When a freshwater input is present, surface water salinity is significantly reduced for both time stamps (immediately after the storm and 42 days after). Stream discharge, as well as rainfall, lead to significantly different salinity contours and after-storm freshwater recovery rate. For the 3 and $9 \mathrm{~m}^{3} / \mathrm{s}$ discharge scenarios (Figs. 4 and 5), freshwater being discharged into the wetland causes the salinity front to move seawards; the larger
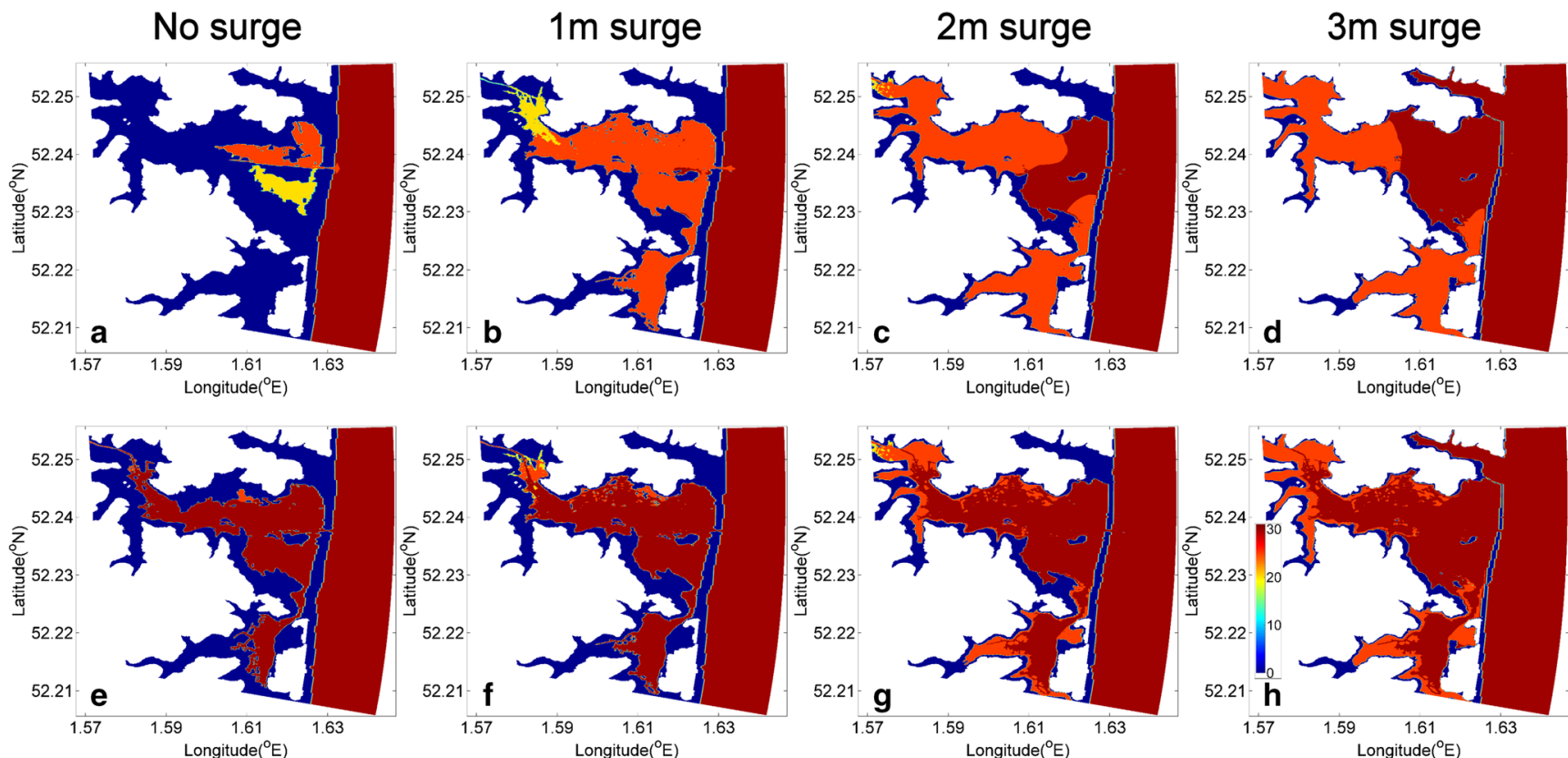

Fig. 3 Salinity of surface water in the marshland for the 4 surge scenarios with $0 \mathrm{~m}^{3} / \mathrm{s}$ fresh water discharge through the west open boundary. a - d are at the end of the breach event for the $0 \mathrm{~m}, 1 \mathrm{~m}, 2 \mathrm{~m}$ and $3 \mathrm{~m}$ surges,
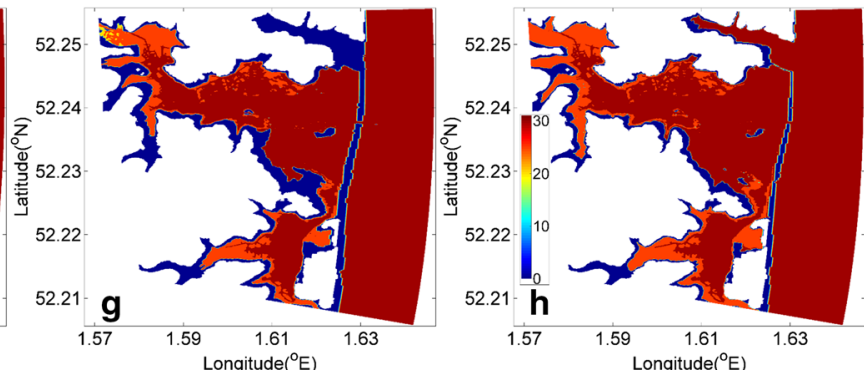

respectively. $\mathbf{e}-\mathbf{h}$ are at 42 days from the end of the breach event for the $0 \mathrm{~m}, 1 \mathrm{~m}, 2 \mathrm{~m}$ and $3 \mathrm{~m}$ surges, respectively. Tested scenarios include barrier breaching at the current sluice location 

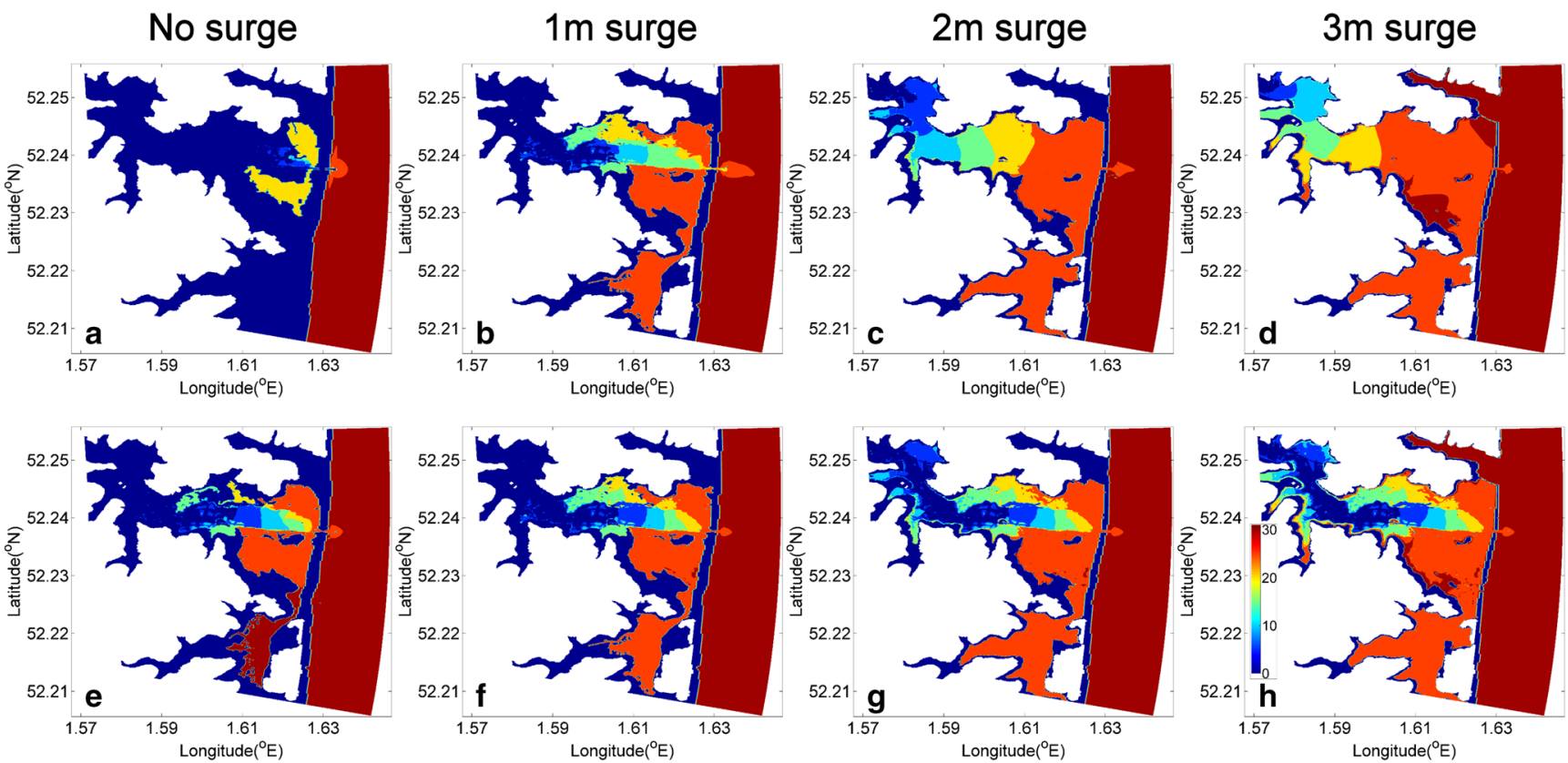

Fig. 4 Salinity of surface water in the marshland for the 4 surge scenarios with $3 \mathrm{~m}^{3} / \mathrm{s}$ fresh water discharge through the west open boundary. a - d are at the end of the breach event for the $0 \mathrm{~m}, 1 \mathrm{~m}, 2 \mathrm{~m}$ and $3 \mathrm{~m}$ surges,

respectively. $\mathbf{e}-\mathbf{h}$ are at 42 days from the end of the breach event for the $0 \mathrm{~m}, 1 \mathrm{~m}, 2 \mathrm{~m}$ and $3 \mathrm{~m}$ surges, respectively

the discharge, the more seaward the salinity front is. Specifically, in the immediate after-storm period, freshwater wedges are found north of the New Cut for both the 3 and 9 $\mathrm{m}^{3} / \mathrm{s}$ discharge scenarios and for the $0 \mathrm{~m}$ and $1 \mathrm{~m}$ surge cases suggesting that the presence of a freshwater input can offset seawater intrusion through the barrier breach even during stormy events.

No surge
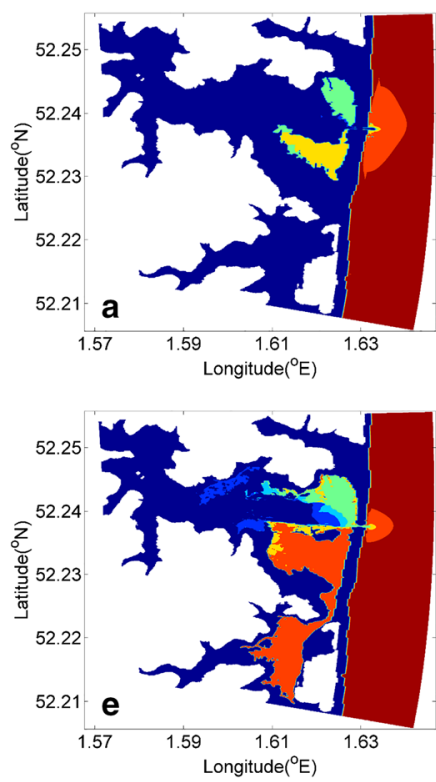

Fig. 5 Salinity of surface water in the marshland for the 4 surge scenarios with $9 \mathrm{~m}^{3} / \mathrm{s}$ fresh water discharge through the west open boundary. a - d are at the end of the breach event for the $0 \mathrm{~m}, 1 \mathrm{~m}, 2 \mathrm{~m}$ and $3 \mathrm{~m}$ surges,

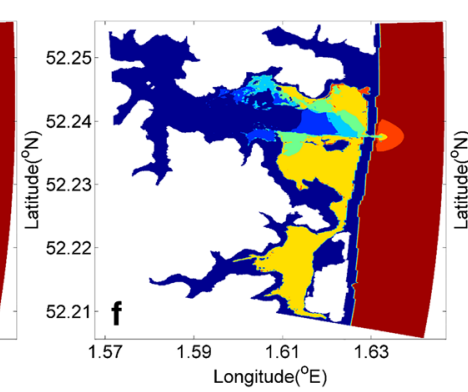

Opposite to the overall increase in salinity over time beyond the storm event observed in the cases without river discharge (Fig. 3), surface water salinity across the wetland of the 3 and $9 \mathrm{~m}^{3} / \mathrm{s}$ discharge scenarios decreases once the surge comes to an end: a freshwater wedge is observable north to the New Cut in all scenarios 42 days after the end of the surge. For the rainfall cases (Fig. 6), although the

\section{$2 \mathrm{~m}$ surge}

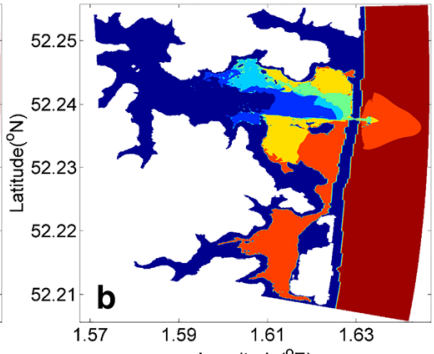

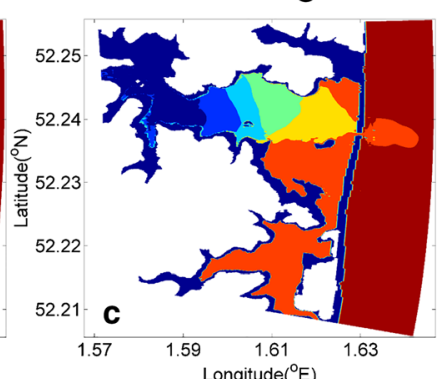
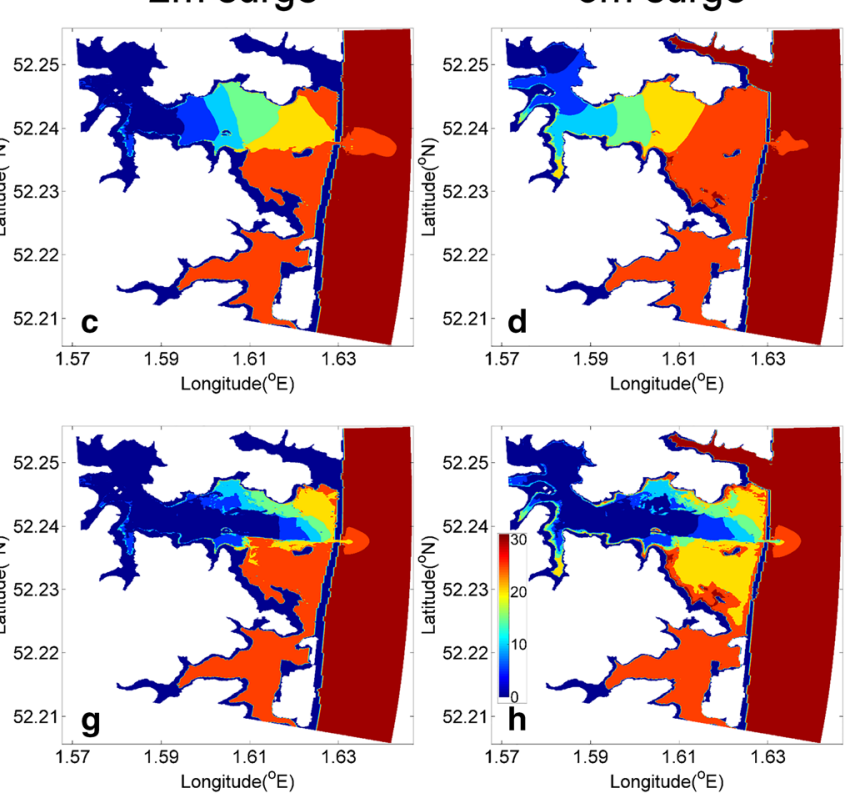

respectively. $\mathbf{e}-\mathbf{h}$ are at 42 days from the end of the breach event for the $0 \mathrm{~m}, 1 \mathrm{~m}, 2 \mathrm{~m}$ and $3 \mathrm{~m}$ surges, respectively 

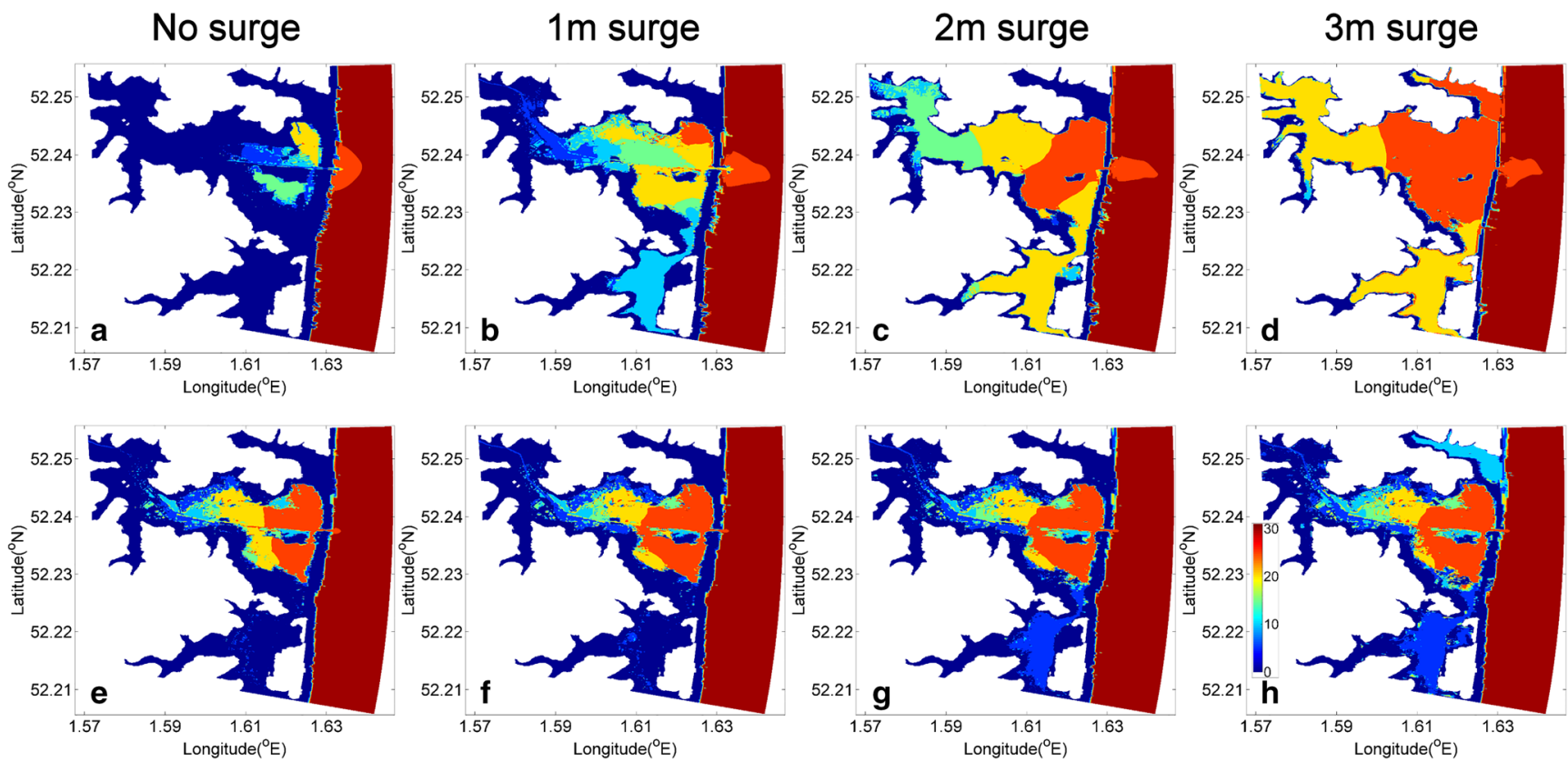

Fig. 6 Salinity of surface water in the marshland for the 4 surge scenarios with rainfall. a - $\mathbf{d}$ are at the end of the breach event for the $0 \mathrm{~m}, 1 \mathrm{~m}, 2 \mathrm{~m}$ and $3 \mathrm{~m}$ surges, respectively. $\mathbf{e}-\mathbf{h}$ are at 42 days from the end of the breach event for the $0 \mathrm{~m}, 1 \mathrm{~m}, 2 \mathrm{~m}$ and $3 \mathrm{~m}$ surges, respectively

more limited landward intrusion of the salinity front is also observed at the end of the surge, freshwater wedges are not formed after 42 days post-storm. Instead, more widely distributed salinity contours are formed, and the contours are similar to each other.

Spatial distribution of surface water salinity under the compound action of SLR and different stream discharge or rainfall, is given in Fig. 7. In comparison with contours at the same time stamp of the corresponding cases without SLR and storm surge, i.e. panel E in Figs. 3, 4, 5 and 6, a SLR scenario of $0.9 \mathrm{~m}$ significantly increases salinity of the surface water in the back-barrier wetland. Also, the area in the wetland affected by seawater is increased in all four cases due to SLR. The freshwater wedge observed in the two river discharge cases without SLR (Figs. 4e and 5e) is absent in the corresponding SLR cases (Fig. $7 \mathrm{~b}$ and c), indicating that the tidal flow in the wetland is stronger than the flow caused by freshwater discharge. Overtopping of the northern end of the coastal
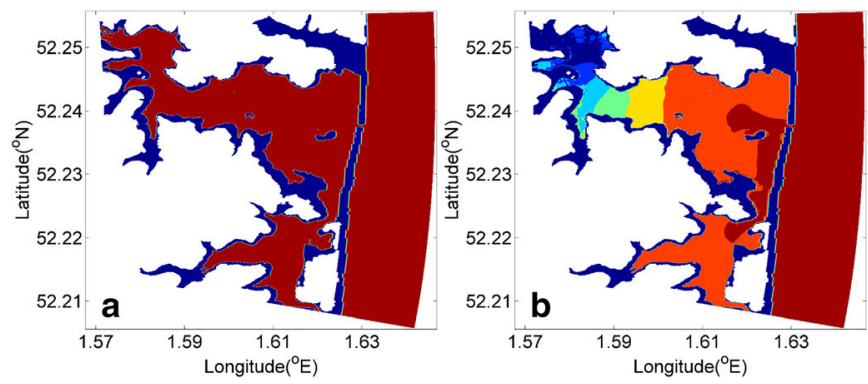

Fig. 7 Salinity of surface water in the marshland at 42 days from the end of the storm for the SLR simulations: a $0 \mathrm{~m}^{3} / \mathrm{s}$ fresh water discharge through the west open boundary; b $3 \mathrm{~m}^{3} / \mathrm{s}$ fresh water discharge defences due to SLR is not observed, although in reality this location may be made more vulnerable to breaching due to coastal erosion associated with SLR.

To scope the temporal trends of salinity in the back-barrier wetland under the above-mentioned scenarios, surface water salinity is sampled at eight locations, four along the New Cut and four on the two sides of the New Cut (Fig. 1), for the duration of the simulation. Figures showing time series of salinity of the above-mentioned cases at the eight locations, as well as the associated discussion, are given in the supplementary material.

\section{Salinity over Distance at the End of the Beach Event}

Salinity at the end of the barrier beach event as a function of distance from the breach of the above-mentioned cases is shown in Fig. 8. For all cases, surface water salinity
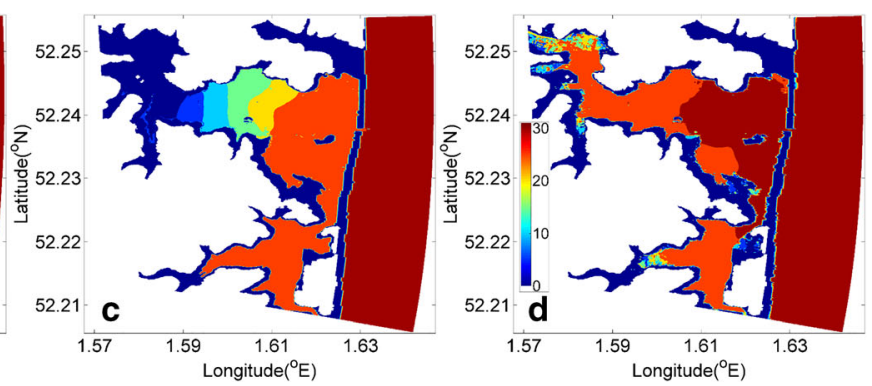

through the west open boundary; c $9 \mathrm{~m}^{3} / \mathrm{s}$ fresh water discharge through the west open boundary; d Rainfall 
Fig. 8 Salinity at the end of the breach event as a function of distance to the breach
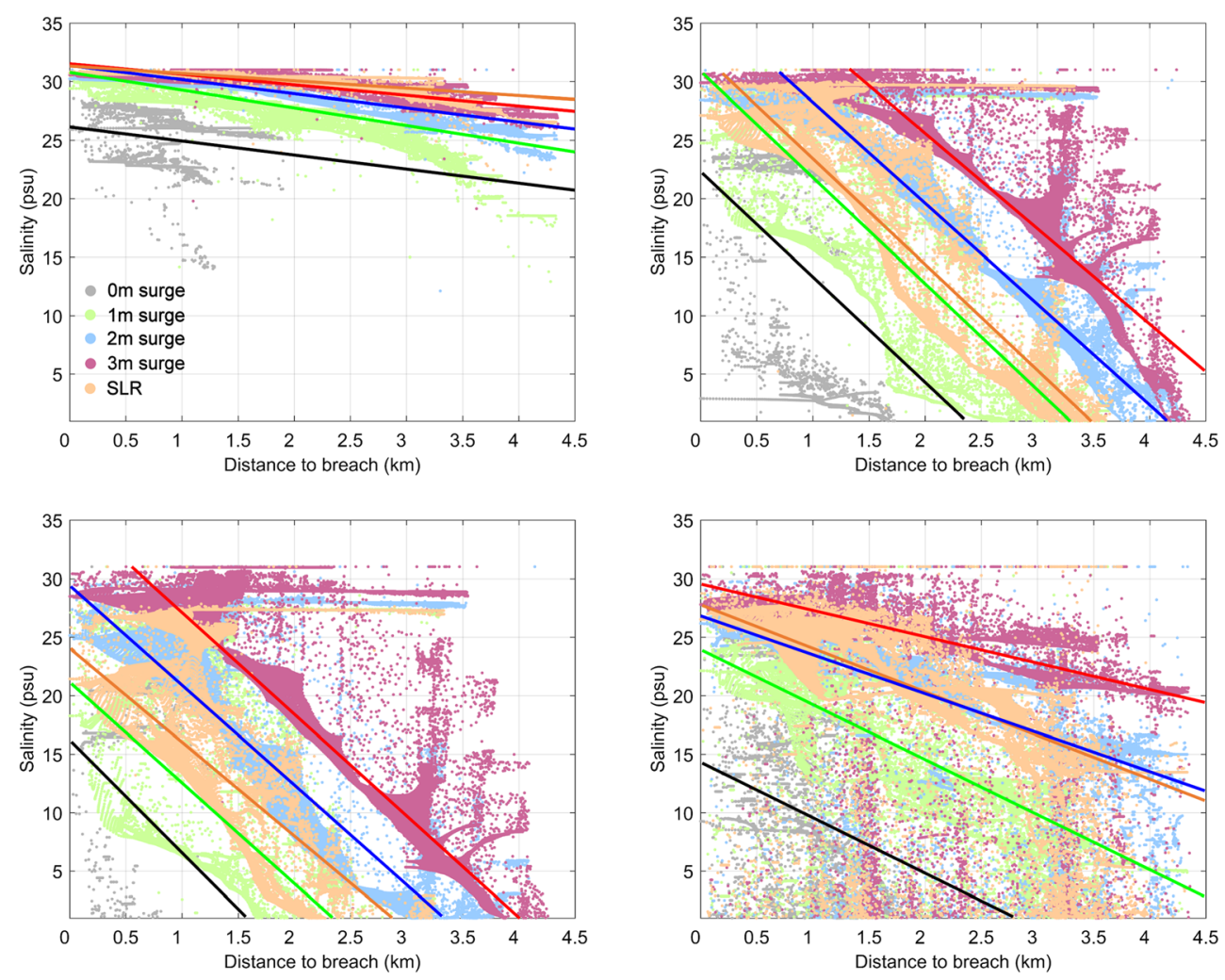

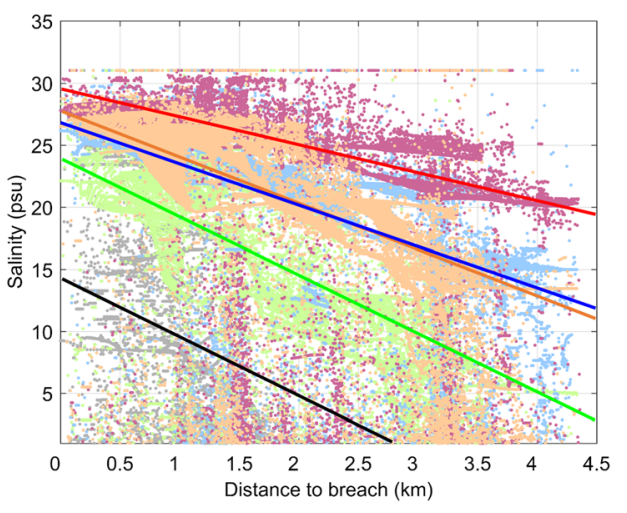

decreases as the distance from the breach increases. Given the same freshwater input, salinity is overall higher when the storm surge is higher. Among the $0 \mathrm{~m}^{3} / \mathrm{s}$ discharge scenarios (Fig. 8a), the case with SLR has the largest surface water salinities. Surface water salinities of the SLR cases at 3 and $9 \mathrm{~m}^{3} / \mathrm{s}$ discharge, however, are lower than those of the corresponding $2 \mathrm{~m}$ surge cases, but larger than those of the $1 \mathrm{~m}$ surge cases (Fig. 8b and c). When the main freshwater resource is rainfall (Fig. 8d), surface water salinities of the SLR case are at the same level of those of the $2 \mathrm{~m}$ surge case.

The lines in Fig. 8 are fitted to the data using least squares regression. When the freshwater input is direct freshwater discharge from the river (Figs. $8 \mathrm{~b}$ and c), the fitted lines in each panel, i.e. same freshwater discharge rate but different surge height, are almost parallel to each other, suggesting that given the same freshwater discharge, the rate of salinity decrease over distance is not sensitive to surge height/SLR. Also, the freshwater recovery rate of the system over distance is higher when freshwater discharge is higher (negative slope of lines in panel $8 \mathrm{~A}$ to $8 \mathrm{C}$ increases). On the other hand, the fitted lines in Fig. $8 \mathrm{~d}$ diverge as the distance to the breach increases. In other words, given the same rainfall, the freshwater recovery rate of the system over distance decreases with increasing storm height. It is also seen from Fig. 8 that the salinity over distance for cases integrating the mitigating effect of rainfall is more widely distributed

Table 1 Effects of surge height, SLR, freshwater discharge and rainfall on salinity over distance at the end of the breach event

\begin{tabular}{|c|c|c|c|c|}
\hline & & \multicolumn{2}{|l|}{ Freshwater discharge $\left(\mathrm{m}^{3} / \mathrm{s}\right)$} & \multirow{2}{*}{$\begin{array}{l}\text { Rainfall } \\
\text { Same record }\end{array}$} \\
\hline & & Constant & Increases from 0 to 9 & \\
\hline \multirow[t]{3}{*}{$\begin{array}{l}\text { Surge/SLR } \\
\qquad(\mathrm{m})\end{array}$} & & $\begin{array}{l}\text { - The rate of salinity decrease over } \\
\text { distance is not sensitive to surge } \\
\text { height/SLR; }\end{array}$ & $\begin{array}{l}\text { - Freshwater recovery rate over } \\
\text { distance increases when } \\
\text { discharge increases; }\end{array}$ & \\
\hline & $\begin{array}{l}\text { Surge increases } \\
\text { from } 1 \text { to } 3\end{array}$ & $\begin{array}{l}\text { - Salinity is overall higher when the } \\
\text { storm surge is higher; }\end{array}$ & & $\begin{array}{l}\text { - Freshwater recovery rate of the system } \\
\text { over distance decreases with increasing } \\
\text { storm height; }\end{array}$ \\
\hline & $\begin{array}{l}\text { Comparison } \\
\text { between surge } \\
\text { and SLR }\end{array}$ & \multicolumn{2}{|c|}{$\begin{array}{l}\text { - SLR has the largest surface water salinities when discharge is } 0 \text {; } \\
\text { - Surface water salinities of the SLR cases are lower than those of the } 2 \mathrm{~m} \\
\text { surge cases, but larger than those of the } 1 \mathrm{~m} \text { surge cases, when discharge } \\
\text { is } 3 \text { and } 9 \text {; }\end{array}$} & $\begin{array}{l}\text { - Surface water salinities of the SLR case } \\
\text { are at the same level of those of the } 2 \mathrm{~m} \\
\text { surge case. }\end{array}$ \\
\hline
\end{tabular}


than that of cases with freshwater discharges. To facilitate comparison, the effects of surge height, SLR, freshwater discharge and rainfall on salinity over distance at the end of the breach event, discussed above, are also listed in Table 1.

\section{Reedbed Die-Back}

A reedbed die-back analysis has been carried out following a threshold criterion assuming that $P$. australis die-back occurs when salinity is above 22.5 psu for a continuous period of 42 days (Hellings and Gallagher 1992; Lissner and Schierup 1997). Results of the cases with storm surges are presented in Fig. 9, in which the yellow shaded areas indicate regions that meet the reedbed die-back criterion (hereafter 'potential dieback area') and the red shaded areas depict the initial distribution of reedbed. The orange shaded areas where the yellow shaded areas overlay with the red shaded areas, therefore, indicate the extent of reedbed lost due to storm-induced saline intrusion into the wetland.

For the $0 \mathrm{~m}^{3} / \mathrm{s}$ discharge cases, most of the wetland is recognized as potential die-back area. Areas north to the Coney Hill cross bank only meet the criterion when a $3 \mathrm{~m}$ surge is imposed. The potential die-back area is significantly reduced for the $3 \mathrm{~m}^{3} / \mathrm{s}$ and $9 \mathrm{~m}^{3} / \mathrm{s}$ discharge cases. In particular, wedgeshaped die-back-free zones stretching to the barrier breach are formed north of the New Cut for the 0-2 m surge scenarios with $3 \mathrm{~m}^{3} / \mathrm{s}$ discharge, and the potential die-back area north to the New Cut becomes almost negligible for the same scenarios with $9 \mathrm{~m}^{3} / \mathrm{s}$ discharge. For both discharges, the area north to the Coney Hill cross bank turns into potential die-back zone only when the surge height is $3 \mathrm{~m}$. For the rainfall cases, the distribution of the potential die-back area is less affected by surge occurrence. In comparison with the freshwater discharge cases, although the potential die-back areas in the main floodplain of the rainfall cases are larger, areas north of the Coney Hill cross bank and southern areas are always die-back-free zones, even when surge height reaches $3 \mathrm{~m}$.

Following the same reedbed die-back threshold criterion mentioned above, reedbed losses for the cases that implemented SLR are presented in Fig. 10. Compared to the corresponding cases without SLR, i.e. panels A, E, I \& M in Fig. 9, SLR of $0.9 \mathrm{~m}$ significantly increases the potential die-back area. Similar to the results shown above for the storm surge cases at $3 \mathrm{~m}^{3} / \mathrm{s}$ and $9 \mathrm{~m}^{3} / \mathrm{s}$ discharge, weak wedge-shaped die-back-free zones are observed for the SLR integrated $3 \mathrm{~m}^{3} / \mathrm{s}$ and $9 \mathrm{~m}^{3} / \mathrm{s}$ discharge cases. The distribution of the potential die-back area of the rainfall case is very similar to that of the $0 \mathrm{~m}^{3} / \mathrm{s}$ discharge case.

Reedbed losses in hectares (areas of orange regions in Figs. 9 and 10) have been calculated for all simulated scenarios and are presented in Fig. 11. For cases that implemented storm surges, reedbed loss increases as surge height increases. Reedbed losses of the cases without any freshwater input (i.e.
$0 \mathrm{~m}^{3} / \mathrm{s}$ discharge) are the highest and can reach 92 ha for the $3 \mathrm{~m}$ surge case. Cases of applied freshwater discharge into the New Cut through the west open boundary of the model undergo smaller reedbed losses in comparison. Reedbed losses for the $3 \mathrm{~m}^{3} / \mathrm{s}$ discharge cases are below 20 ha until surge height increases to $3 \mathrm{~m}$, in which case the loss increases to 54 ha. Similarly, for the $9 \mathrm{~m}^{3} / \mathrm{s}$ discharge cases, reedbed losses are almost negligible until the $3 \mathrm{~m}$ surge increases the loss to nearly 20 ha. Reedbed losses for the rainfall cases remain at a level of 50-60 ha, regardless of the surge height.

SLR of $0.9 \mathrm{~m}$ is observed to increase the reedbed loss of all four cases. Freshwater discharge through the main channel of the ditch network within the wetland can effectively reduce the SLR-induced reedbed loss. In particular, a discharge of $9 \mathrm{~m}^{3} / \mathrm{s}$ can reduce the reedbed loss from 74 ha to $5 \mathrm{ha}$. On the other hand, very little effect of rainfall on reedbed loss is observed. Compared to the impact of storm surges, reedbed loss due to SLR is equal to the damage caused by a $2 \mathrm{~m}$ surge, given no freshwater is being input into the wetland. For the $3 \mathrm{~m}^{3} / \mathrm{s}$ discharge cases, the reedbed loss caused by SLR is slightly larger than that caused by the $3 \mathrm{~m}$ storm surge; the losses are 58 ha and 54 ha, respectively. The SLR-caused reedbed loss with the 9 $\mathrm{m}^{3} / \mathrm{s}$ discharge case lies between the damage caused by the $2 \mathrm{~m}$ and $3 \mathrm{~m}$ surges with the same rate of freshwater input. When rainfall is the source of freshwater input of the system, SLR causes a significantly larger destruction to the reedbed of the wetland than storm surges. While the reedbed losses caused by the storms remain at a level of 50-60 ha, the loss is increased to 74 ha for the SLR case.

\section{Discussion}

This research explores reedbed die-back in a coastal backbarrier wetland following a barrier breaching event. The modelled salinization of wetland areas due to sea/freshwater exchange, storm events and SLR has been identified as a major threat for reedbeds, and a threshold criterion is here used to determine the survival/die-back of reedbeds under different external forcing scenarios. As such, the modelling can be viewed as a tool for scoping the impact of different flooding phenomena or the consequences of alternative management strategies on wetland habitats and biodiversity. Although not exhaustive, the value of this approach lies in exploring the vulnerability of coastal wetlands to climate and coastal change under 'no active intervention' shoreline management, from event to centennial timescales (Cowell and Thom 1994), and in shaping strategies and interventions for effective 'managed realignment'. Here, we examine the modelling results in relation to how they may feed into decision support for coastal wetland management and climate change adaptation. 

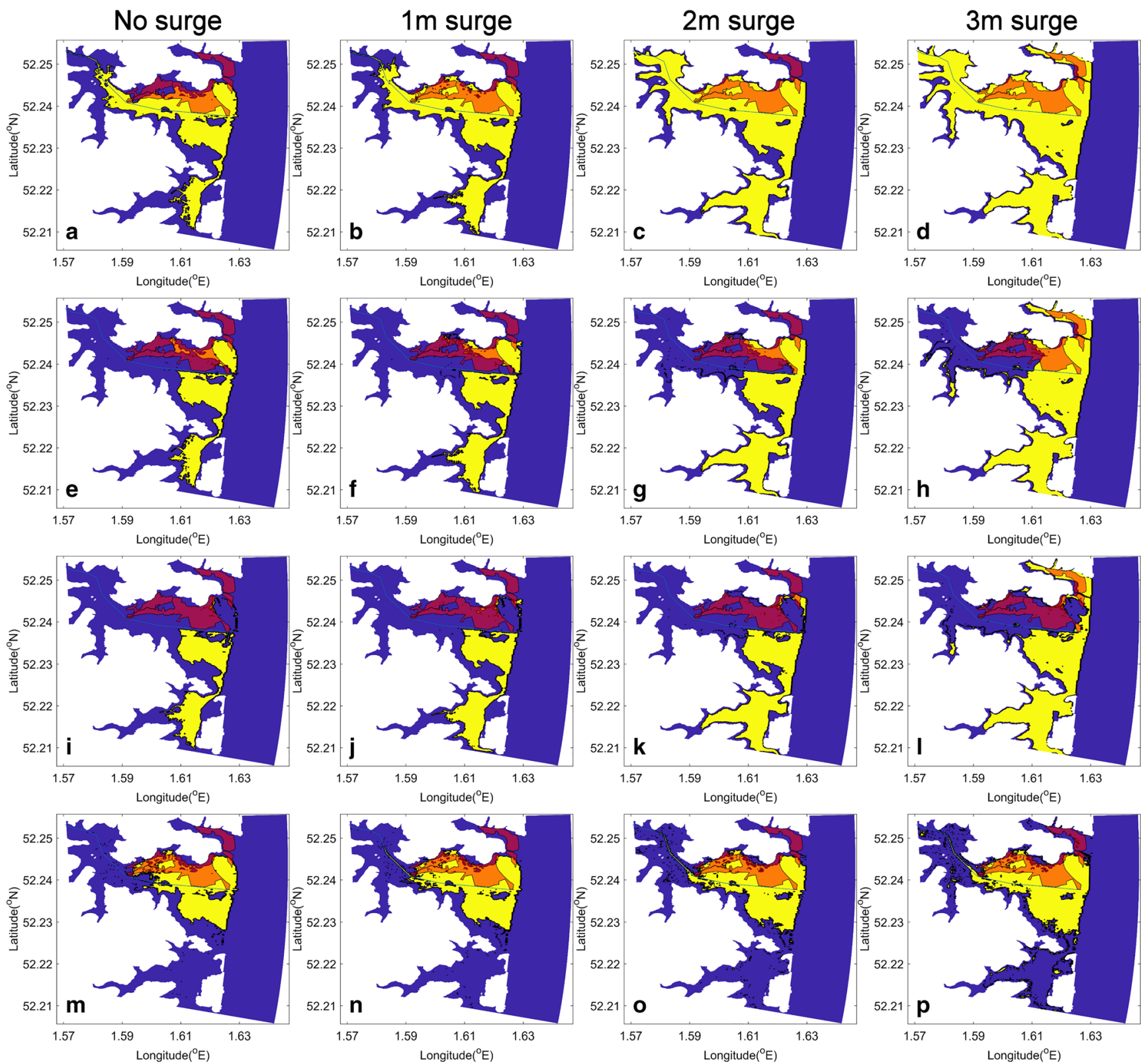

Regions meet reedbed die-back criteria $\square$ Initial distribution of reedbed $\square$ Reedbed loss

Fig. 9 Reedbed die-back of the surge scenarios. a - $\mathbf{d}$ are for the $0-3 \mathrm{~m}$ surges, respectively, with $0 \mathrm{~m}^{3} / \mathrm{s}$ discharge applied. $\mathbf{e}-\mathbf{h}$ are for the $0-3 \mathrm{~m}$ surges, respectively, with $3 \mathrm{~m}^{3} / \mathrm{s}$ discharge applied. (I) - (L) are for the 0

$3 \mathrm{~m}$ surges, respectively, with $9 \mathrm{~m}^{3} / \mathrm{s}$ discharge applied. $\mathbf{m}$ - $\mathbf{p}$ are for the $0-3 \mathrm{~m}$ surges, respectively, with historical daily rainfall applied
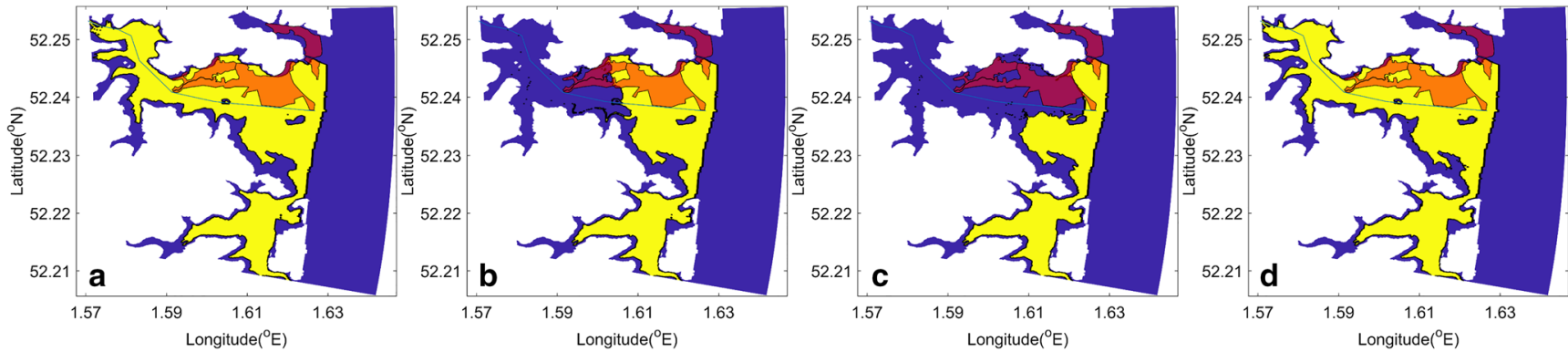

Regions meet reedbed die-back criteria $\square$ Initial distribution of reedbed $\square$ Reedbed loss

Fig. 10 Reedbed die-back of the SLR scenarios: a $0 \mathrm{~m}^{3} / \mathrm{s}$ discharge; $\mathbf{b} 3 \mathrm{~m}^{3} / \mathrm{s}$ discharge; $9 \mathrm{~m}^{3} / \mathrm{s}$ discharge; $\mathbf{d}$ Historical daily rainfall 
Fig. 11 Reedbed loss in hectares for the simulated scenarios

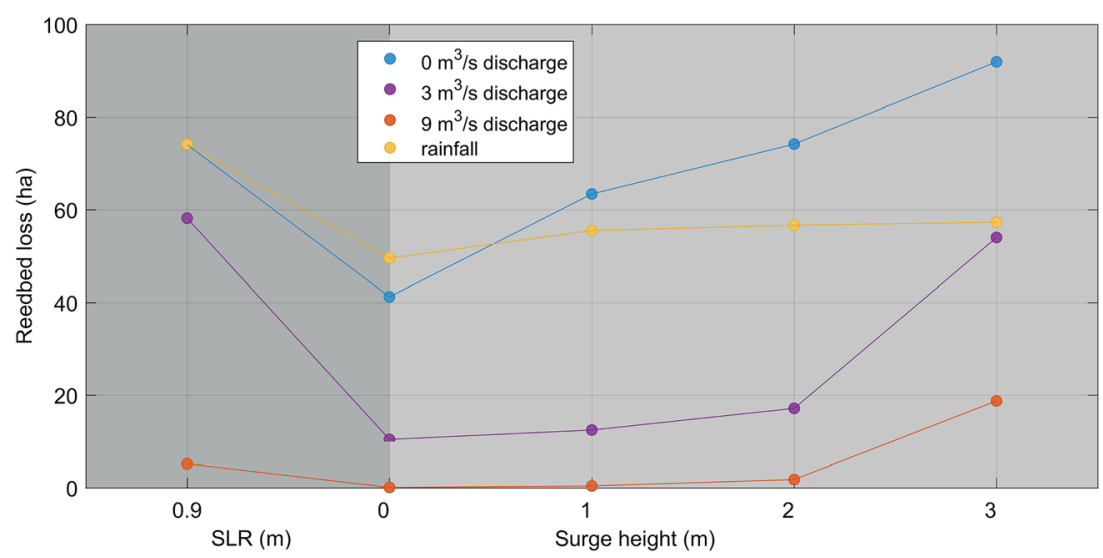

Our results show that without any mitigation plan in place, such as regulated freshwater inputs, the majority of the current reedbeds in Minsmere will be lost due to increased salinity in case of breaching of the coastal defences. For example, even under calm conditions ( $0 \mathrm{~m}$ surge) and without SLR, water exchange caused by the breaching alone can lead to a $44 \%$ loss of the current reedbeds extent, and the reedbed loss under calm conditions but with $0.9 \mathrm{~m}$ SLR can increase to $\sim 78 \%$ (Fig. 11). In this respect, the reedbed habitat currently exhibits considerable vulnerability to event-based barrier breaching during periods of low freshwater discharge, which increases substantially with SLR. This implies a requirement for both immediate and long-term mitigation, likely in the form of 'compensatory habitat' creation, which is already in plan for the Ouse and Nene Washes (Natural England. 2016).

Tests incorporating freshwater input in the form of direct river discharge were run to address saline intrusion compared with cases with rainfall. Compared to rainfall, which provides an evenly distributed freshwater input for the area, the impact of river discharge is more spatially-focused, and the spatiallylimited distribution of freshwater is further constrained by the topography. Therefore, the chances of reedbed survival are only increased for areas that are closer to the freshwater passage. However, despite the small discharge values, discharge inputs are more efficient than rainfall in offsetting the salinity increase, and hence for the test case herein deliver more effective mitigation in reducing total reedbed die-back for surge values up to $3 \mathrm{~m}$ and for SLR up to $0.9 \mathrm{~m}$. In the immediate term, i.e. wetland resilience to breaching under 'no active intervention' scenario, the reedbeds are located where freshwater passage is good and, hence, if breaching took place during winter or periods of high river discharge (as is often associated with storms), the reedbed loss would be moderated substantially. Presently, it is rare that freshwater discharge into Minsmere reaches the modelled high scenario to achieve complete resilience to tidal ingress, and if breaching took place during summer the effects on reedbed extent would be far reaching. In the long-term, aside from the costs of implementing a water storage and management scheme for mitigation by river discharge input, additional challenges come from climate change and increased domestic and agricultural water demand in the south and east of England (Defra 2013). In relation to climate change, the UK Climate Projections 2018 (UKCP18) projected that average summer rainfall in the UK could decrease by up to $47 \%$ while average winter rainfall could increase by up to $35 \%$ by 2070 . Such a future would necessitate an effective water storage and management scheme to maintain reedbed resilience during the summer months. Overall, the model results suggest that continuous and targeted freshwater discharge could be regarded as a potential mitigation strategy under both 'no active intervention' and 'managed realignment' scenarios but only if sufficient freshwater resources are available and can be managed appropriately. This would seem less likely for a 'managed realignment' future, and thus the inland habitat compensation option, described above, is a more viable option.

Comparison between the impacts of storm surges and SLR has been carried out. Our results show that in terms of hectare loss of reedbeds, a $0.9 \mathrm{~m}$ SLR has a greater impact than surges up to $2 \mathrm{~m}$ height with no SLR, especially for cases where wetland loss mitigation measures are being implemented with 3 and $9 \mathrm{~m}^{3} / \mathrm{s}$ discharge regulation. This is due to the fact that for the SLR scenarios the baseline sea level is continuously higher throughout the entire simulated period, which facilitates the ingress of seawater into the wetland, hence the increase of salinity of the surface water. Further, compared to the temporary nature of the water level increase caused by storm surges, the raising of baseline mean sea level caused by SLR is an event with a much longer duration which can lead to longlasting flooding of the wetland, causing greater damage to the vegetation of coastal wetlands through prolonged submergence of the plants and salinization of the water system. In terms of decision support, this implies that the current mosaic of habitats in Minsmere wetlands is unlikely to be sustained into management epoch 2 (20-50 years), and that another wetland complex will be required for epoch 3 (50-100 years) - one that is much more aligned with a tidally flushed barrier estuary (Roy et al. 1994), characterised by tidal creeks, 
mudflats, saltmarshes and marginal reed swamps. Whilst this would represent a significant change in the natural resource base, it would essentially be a return to the 'Haven' that existed on site prior to its closure in the eighteenth century (Pye and Blott 2006).

As a nature reserve, the study site serves as a good representative of coastal habitats that are homes to a wide range of plants and animals. Therefore, in addition to the die-back of reeds, increased salinity in the wetland would also pose pressure on the survival of other species. Our results show that the current reedbed extent is likely to shrink over the long term under the threat of increased salinity in the wetland, which agrees with previous finding suggesting that the expansion of $P$. australis is limited by high salinities (Chambers et al. 1999). However, the salinization of the wetland does not necessarily mean a complete eradication of the existing habitat and the reliant communities which are adaptive to the changing environment. The intrusion of saline water could present opportunities for reedbed colonization on the landward side of the domain, hence the relocation of animals that are dependent on reedbed. Indeed, colonization and expansion of $P$. australis on the high marsh areas under certain conditions have been widely reported in the US (Chambers et al. 1999; Bart and Hartman 2000; Bertness et al. 2002). However, apart from hydrodynamic factors, nutrient regime also plays an important role in determining the early establishment and growth of reedbeds (Chambers et al. 1999). In this respect, habitat compensation due to wetland development elsewhere represents a more reliable strategy associated with 'managed realignment' of Minsmere.

In addition to the above-mentioned potential migration of the reedbed and its reliant ecological communities on the high marsh, an increased surface water salinity in the wetland could also facilitate the establishment of plants with higher salttolerance in the low marsh (Donnelly and Bertness 2001), and thus lead to a habitat shift. For example, competitive interactions may exist between $P$. australis and S. alterniflora at moderate salinities, but $S$. alterniflora is more likely to survive and replace $P$. australis at high salinities due to specialised glands on the leaves which allow efficient osmoregulation and salt excretion (Howes et al. 1986; Vasquez et al. 2006; Medeiros et al. 2013). Therefore, controlled introduction of highly salttolerant plants and their dependent communities in low marsh areas could potentially serve as a solution to retain bio-diversity posterior to the salinization of back-barrier brackish wetlands.

The results presented in this research are based on one idealized breach location, i.e. the manually controlled sluice of the drainage system in the wetland; this idealized scenario was chosen as it maximizes the seawater ingress into the system through transmission within the existing drainage network. In which case, it might be regarded as a 'worst case' for seawater ingress, increased salinity and reedbed die back. However, breaching can happen at different locations, which then leads to the question of how critical the breach location is in terms of inundation extent, water salinization and ecosystem destruction. For instance, had the breach happened north of Coney Hill cross bank, the main wetland area would likely be protected by this secondary defence from the impacts of both storm surges and SLR. Also, the damage caused to the wetland is likely to be reduced if the breach is situated further south of its current location, as the area south of the New Cut is higher elevation with fewer drainage channels and weaker channel connectivity, hence reduced water exchange and salinity diffusion. When the breach is located between the sluice and the cross bank, sea water ingress would be slower if the seawater being flushed into the wetland remains confined within the drainage channels, relying on the channel network to progress. However, if the amount of seawater input is large enough to overflow the channel banks and bypass the channel network to diffuse across the wetland, the efficiency of sea water ingress is then independent of the location of the breach.

In considering the implications of seawater ingress for both the 'no active intervention' and 'managed realignment' futures, wetland response need not have to develop naturally following breaching. Direct interventions in the back-barrier to steer landscape evolution in the wetland, such as creating creeks and developing the necessary topography, can ultimately compensate for habitat loss induced by seawater intrusion (e.g. Dale et al. 2017, 2018; Lawrence et al. 2018). For example, the fast seawater ingress promoted by high connectivity of the drainage network mentioned above could be impeded by construction of embankments that disconnect the network. In a like manner, channels could be created by design to route seawater away from the reedbeds if the goal was to retain the reedbeds at their current establishment.

A numerical model (Delft3D) is used in this research as a tool to study the impact of barrier breaching on a back-barrier wetland located on a micro-mesotidal coast. The methodology applied in this research to investigate responses of wetland vegetation to environmental stressors, i.e. combining key environmental factors predicted by state-of-the-art numerical models and the tolerance of plants to these factors, is readily transferable to studies with a similar research focus and, indeed, to sites where 'managed realigment' is an agreed option for coastal resource management over the longer term. Similarly, the outcomes of this research illustrate the potential impacts of environmental changes on vegetation in micro-mesotidal back-barrier wetlands, e.g. Donaña National Park in southern Spain and Elkhorn Slough National Estuarine Research Reserve in California. Tidal environments characterized by low tidal range have been found to experience restricted water exchange between the enclosed coastal wetlands and coastal waters (Childers and Day Jr 1988; Ibñez et al. 2002; SánchezCarrillo et al. 2009), which also suggests a limited exchange of salt between the two water bodies. It can, therefore, be deduced that meso- and macrotidal environments which typically have larger tidal prism are likely to undergo greater water and 
salt exchange and, hence, experience more severe breachinginduced surface water salinization.

\section{Conclusions}

This research explores the potential state of a coastal wetland with a barrier breach either due to coastal erosion consequent upon accelerated sea-level rise, instantaneous breaching during a storm, or as a result of human intervention. Predicted extensive vegetation die-back due to prolonged highly saline conditions caused by sea/freshwater exchange through the breach revealed the vulnerability of coastal back-barrier wetland. Analyses were conducted under the compound action of SLR, freshwater inputs and different storm surge scenarios. The comparison between storm surges and SLR-induced impacts in terms of hectares loss in reedbeds revealed that a $0.9 \mathrm{~m}$ SLR (RCP 8.5 projection for year 2100) had a greater impact than a surge up to $2 \mathrm{~m}$ height with no SLR, either with or without regulative freshwater input. The potential of utilizing continuous and targeted freshwater discharge to mitigate SLR and/or surge-induced disruption on wetland salinity to guarantee habitat stability has been investigated. We found that constant freshwater discharge can largely reduce areas affected by salinity increments and areas possibly subject to reedbed die-back. This is, of course, dependent on the availability of sufficient stream discharge to meet the required regulatory demand.

The numerical model used in this research provides a useful tool for scoping the impact of barrier breaching on backbarrier wetlands under both 'no active intervention' and 'managed realignment' options for coastal resource management. Due to the wide extent of coastal wetlands, and their importance in supporting bio-diversity and providing coastal protection, the findings of this research are highly important to the planning and management of coastal wetlands. This can be reflected in the identification of vulnerable locations, projected areal changes in wetland composition and distribution, and the evaluation of potential mitigation strategies according to the time frame being considered. The model therefore offers an important tool for exploring the potential consequences of alternative management strategies under different environmental forcings.

Acknowledgments This work was supported by the NERC research grant: NE/N015614/1, Physical and biological dynamic coastal processes and their role in coastal recovery (BLUE-coast), and the N8-AgriFood award, NCG10111, Toward an integrated approach for salt intrusion and salinization management in soil and aquifers for sustainable agriculture.

Open Access This article is distributed under the terms of the Creative Commons Attribution 4.0 International License (http:// creativecommons.org/licenses/by/4.0/), which permits unrestricted use, distribution, and reproduction in any medium, provided you give appropriate credit to the original author(s) and the source, provide a link to the Creative Commons license, and indicate if changes were made.

\section{References}

Alongi DM (2008) Mangrove forests: resilience, protection from tsunamis, and responses to global climate change. Estuarine, Coastal and Shelf Science 76(1):1-13

Bamber, J. L., Oppenheimer, M., Kopp, R. E., Aspinall, W. P., \& Cooke, R. M. (2019). Ice sheet contributions to future sea-level rise from structured expert judgment. Proceedings of the National Academy of Sciences, 201817205

Bart D, Hartman JM (2000) Environmental determinants of Phragmites australis expansion in a New Jersey salt marsh: an experimental approach. Oikos 89(1):59-69

Bertness MD, Ewanchuk PJ, Silliman BR (2002) Anthropogenic modification of New England salt marsh landscapes. Proceedings of the National Academy of Sciences 99(3):1395-1398

Blankespoor B, Dasgupta S, Laplante B (2014) Sea-level rise and coastal wetlands. Ambio 43(8):996-1005

Brady AF, Boda CS (2017) How do we know if managed realignment for coastal habitat compensation is successful? Insights from the implementation of the EU birds and habitats directive in England. Ocean and Coastal Management 143:164-174

Brooks SM, Spencer T, Boreham S (2012) Deriving mechanisms and thresholds for cliff retreat in soft-rock cliffs under changing climates: rapidly retreating cliffs of the Suffolk coast, UK. Geomorphology 153:48-60

Burningham H, French J (2017) Understanding coastal change using shoreline trend analysis supported by cluster-based segmentation. Geomorphology 282:131-149

Chambers LG, Guevara R, Boyer JN, Troxler TG, Davis SE (2016) Effects of salinity and inundation on microbial community structure and function in a mangrove peat soil. Wetlands 36(2):361-371

Chambers RM, Meyerson LA, Saltonstall K (1999) Expansion of Phragmites australis into tidal wetlands of North America. Aquatic Botany 64(3-4):261-273

Childers DL, Day JW Jr (1988) A flow-through flume technique for quantifying nutrient and materials fluxes in microtidal estuaries. Estuarine, Coastal and Shelf Science 27(5):483-494

Cowell PJ, Thom BG (1994) Morphodynamics of coastal evolution. Cambridge University Press, Cambridge, pp 33-86

Craft C, Clough J, Ehman J, Joye S, Park R, Pennings S, Guo H, Machmuller M (2009) Forecasting the effects of accelerated sealevel rise on tidal marsh ecosystem services. Frontiers in Ecology and the Environment 7(2):73-78

Dale J, Burgess HM, Cundy AB (2017) Sedimentation rhythms and hydrodynamics in two engineered environments in an open coast managed realignment site. Marine Geology 383:120-131

Dale J, Burgess HM, Burnside NG, Kilkie P, Nash DJ, Cundy AB (2018) The evolution of embryonic creek systems in a recently inundated large open coast managed realignment site. Anthropocene Coasts $1(1): 16-33$

Defra (2013) Making the most of every drop: Consultation on reforming the water abstraction system, In: Affairs, D.f.E.F.R. (Ed.). Defra, London

DeLaune RD, Pezeshki SR, Patrick WH Jr (1987) Response of coastal plants to increase in submergence and salinity. Journal of Coastal Research:535-546 
DELFT Hydraulics (2014) Delft3D-FLOW User Manual: Simulation of multi-dimensional hydrodynamic flows and transport phenomena. Tech. rep., including sediments. Technical report

Donnelly JP, Bertness MD (2001) Rapid shoreward encroachment of salt marsh cordgrass in response to accelerated sea-level rise. Proceedings of the National Academy of Sciences 98(25):14218 14223

Duever MJ, Meeder JF, Meeder LC, McCollom JM (1994) The climate of South Florida and its role in shaping the Everglades ecosystem. The ecosystem and its restoration, Everglades, pp 225-248

EA (2009) Planning a sustainable approach - Minsmere flood risk management study. UK Environmental Agency

Engloner AI (2009) Structure, growth dynamics and biomass of reed (Phragmites australis) - a review. Flora-Morphology, Distribution, Functional Ecology of Plants 204(5):331-346

Esteves LS, Williams JJ (2017) Managed realignment in Europe: a synthesis of methods, achievements and challenges. In: Bilkovic, D.M.; Mitchell, M.M.; Toft, J.D. and La Peyre. M.K. (eds.), Living Shorelines: The Science and Management of Nature-based Coastal Protection. CRC Press/Taylor \& Francis Group, p.157-180

Field CR, Gjerdrum C, Elphick CS (2016) Forest resistance to sea-level rise prevents landward migration of tidal marsh. Biological Conservation 201:363-369

Friess DA, Möller I, Spencer T, Smith GM, Thomson AG, Hill RA (2014) Coastal saltmarsh managed realignment drives rapid breach inlet and external creek evolution, Freiston shore (UK). Geomorphology 208:22-33

Gable FJ, Gentile JH, Aubrey DG (1990) Global climatic issues in the coastal wider Caribbean region. Environmental Conservation 17(1): $51-60$

Garbutt RA, Reading CJ, Wolters M, Gray AJ, Rothery P (2006) Monitoring the development of intertidal habitats on former agricultural land after the managed realignment of coastal defences at Tollesbury, Essex, UK. Marine Pollution Bulletin 53(1-4):155-164

Gedan KB, Silliman BR, Bertness MD (2009) Centuries of human-driven change in salt marsh ecosystems. Annual review of marine science, $1,117-141$

Gedan KB, Kirwan ML, Wolanski E, Barbier EB, Silliman BR (2011) The present and future role of coastal wetland vegetation in protecting shorelines: answering recent challenges to the paradigm. Climatic Change 106(1):7-29

Gilman E, Van Lavieren H, Ellison JC, Jungblut V, Wilson L, Areki F, Sauni Jr I (2006) Pacific Island mangroves in a changing climate and rising sea. UNEP Regional Seas Reports and Studies No. 179, UNEP, Nairobi, pp 58

Grinsted A, Jevrejeva S, Riva RE, Dahl-Jensen D (2015) Sea level rise projections for northern Europe under RCP8. 5. Climate Research 64(1):15-23

Halcrow Group Ltd, HR Wallingford, John Chatterton Associates (2001) National appraisal of assets at risk of flooding and coastal erosion in England and Wales. Final report for the Department of Environment. Food and Rural Affairs, London

Hamilton CA, Kirby JR, Lane TP, Plater AJ, Waller MP (2019) Sediment supply and barrier dynamics as driving mechanisms of Holocene coastal change for the southern North Sea basin. Quaternary International 500:147-158

Hellings SE, Gallagher JL (1992) The effects of salinity and flooding on Phragmites australis. Journal of Applied Ecology, 29, 41-49

Horton BP, Shennan I, Bradley SL, Cahill N, Kirwan M, Kopp RE, Shaw TA (2018) Predicting marsh vulnerability to sea-level rise using Holocene relative sea-level data. Nature Communications 9(1):2687

Howes BL, Dacey JWH, Goehringer DD (1986) Factors controlling the growth form of Spartina alterniflora: feedbacks between aboveground production, sediment oxidation, nitrogen and salinity. The Journal of Ecology 74:881-898
Hume TM, Snelder T, Weatherhead M, Liefting R (2007) A controlling factor approach to estuary classification. Ocean and Coastal Management 50(11-12):905-929

Ibñez C, Curco A, Day JW, Prat N (2002) Structure and productivity of microtidal Mediterranean coastal marshes. In: Concepts and controversies in tidal marsh ecology. Springer, Dordrecht, pp 107-136

Jiang J, DeAngelis DL, Anderson GH, Smith TJ (2014) Analysis and simulation of propagule dispersal and salinity intrusion from storm surge on the movement of a marsh-mangrove ecotone in South Florida. Estuaries and Coasts 37(1):24-35

Kirwan ML, Temmerman S, Skeehan EE, Guntenspergen GR, Fagherazzi S (2016) Overestimation of marsh vulnerability to sea level rise. Nature Climate Change 6(3):253

Lawrence PJ, Smith GR, Sullivan MJ, Mossman HL (2018) Restored saltmarshes lack the topographic diversity found in natural habitat. Ecological Engineering 115:58-66

Leonardi N, Fagherazzi S (2014) How waves shape salt marshes. Geology 42:887-890

Leonardi N, Carnacina I, Donatelli C, Ganju NK, Plater AJ, Schuerch M, Temmerman S (2017) Dynamic interactions between coastal storms and salt marshes: a review. Geomorphology

Leonardi N, Plater AJ (2017) Residual flow patterns and morphological changes along a macro-and meso-tidal coastline. Advances in Water Resources 109:290-301

Li X, Bellerby R, Craft C, Widney SE (2018) Coastal wetland loss, consequences, and challenges for restoration. Anthropocene Coasts 1(0):1-15

Lissner J, Schierup HH (1997) Effects of salinity on the growth of Phragmites australis. Aquatic Botany 55(4):247-260

Lovelock CE, Cahoon DR, Friess DA, Guntenspergen GR, Krauss KW, Reef R, Rogers K, Saunders ML, Sidik F, Swales A, Saintilan N (2015) The vulnerability of indo-Pacific mangrove forests to sealevel rise. Nature 526(7574):559-563

Lyddon C, Brown JM, Leonardi N, Plater AJ (2018) Flood Hazard assessment for a hyper-tidal estuary as a function of tide-surgemorphology interaction. Estuaries and Coasts, 41(6), 1565-1586

Matoh T, Matsushita N, Takahashi E (1988) Salt tolerance of the reed plant Phragmites communis. Physiologia Plantarum 72(1):8-14

McFadden L, Spencer T, Nicholls RJ (2007) Broad-scale modelling of coastal wetlands: what is required? Hydrobiologia 577(1):5-15

McKee M, White JR, Putnam-Duhon LA (2016) Simulated storm surge effects on freshwater coastal wetland soil porewater salinity and extractable ammonium levels: implications for marsh recovery after storm surge. Estuarine, Coastal and Shelf Science 181:338-344

Medeiros DL, White DS, Howes BL (2013) Replacement of Phragmites australis by Spartina alterniflora: the role of competition and salinity. Wetlands 33(3):421-430

Michener WK, Blood ER, Bildstein KL, Brinson MM, Gardner LR (1997) Climate change, hurricanes and tropical storms, and rising sea level in coastal wetlands. Ecological Applications 7(3):770-801

Milliman JD, Broadus JM, Gable F (1989) Environmental and economic implications of rising sea level and subsiding deltas: the Nile and Bengal examples. Ambio:340-345

Natural England (2016) Increasing the resilience of the UK's Special Protected Areas to climate change. Case Study: MinsmereWalberswick. Natural England Commissioned Report NECR202a, Natural England, 35p

Ndebele T, Forgie V (2017) Estimating the economic benefits of a wetland restoration programme in New Zealand: a contingent valuation approach. Economic Analysis and Policy 55:75-89

Orr DW, Ogden JC (1992) The impact of hurricane Andrew on the ecosystems of South Florida. Conservation Biology 6(4):488-490

Plater A, Kirby J (2006) The potential for perimarine wetlands as an ecohydrological and phytotechnological management tool in the Guadiana estuary, Portugal. Estuarine, Coastal and Shelf Science 70(1-2):98-108 
Prime T, Brown JM, Plater AJ, Dolphin T, Fernand L (2015) Morphological control on Overwashing Hazard at multiple energy generation installations. In 14th International Workshop on Wave Hindcasting and Forecasting and 5th Coastal Hazards Symposium

Pye K, Blott SJ (2006) Coastal processes and morphological change in the Dunwich-Sizewell area, Suffolk, UK. Journal of Coastal Research 223:453-473

Rangel-Buitrago N, de Jonge VN, Neal W (2018) How to make integrated coastal Erosion management a reality. Ocean and Coastal Management 156:290-299

Ranwell DS (1964) Spartina salt marshes in southern England: II. Rate and seasonal pattern of sediment accretion. The Journal of Ecology, 79-94

Robbins CW, Meyer WS, Prathapar SA, White RJG (1991) Understanding salt and sodium in soils, irrigation water and shallow groundwaters. CSIRO Water Resources Series, 4 (1991). Canberra

Roman CT, Niering WA, Warren RS (1984) Salt marsh vegetation change in response to tidal restriction. Environmental Management 8(2): 141-149

Roy PS, Cowell PJ, Ferland MA, Thom BG (1994) Wave-dominated coasts. Coastal evolution: Late Quaternary shoreline morphodynamics. Cambridge University Press, Cambridge (1997), pp 121-153

Rupp-Armstrong S, Nicholls RJ (2007) Coastal and estuarine retreat: a comparison of the application of managed realignment in England and Germany. Journal of Coastal Research, 23(6), 1418-1430

Sánchez-Carrillo S, Sánchez-Andrés R, Alatorre LC, Angeler DG, Álvarez-Cobelas M, Arreola-Lizárraga JA (2009) Nutrient fluxes in a semi-arid microtidal mangrove wetland in the Gulf of California. Estuarine, Coastal and Shelf Science 82(4):654-662

Schieder NW, Walters DC, Kirwan ML (2018) Massive upland to wetland conversion compensated for historical marsh loss in Chesapeake Bay, USA. Estuaries and Coasts, 41(4), 940-951

Sternberg LDSL, Teh SY, Ewe SM, Miralles-Wilhelm F, DeAngelis DL (2007) Competition between hardwood hammocks and mangroves. Ecosystems 10(4):648-660

Teh SY, DeAngelis DL, Sternberg LDSL, Miralles-Wilhelm FR, Smith TJ, Koh HL (2008) A simulation model for projecting changes in salinity concentrations and species dominance in the coastal margin habitats of the Everglades. Ecological Modelling 213(2):245-256

Tovey EL, Pontee NI, Harvey R (2009) Award winning managed realignment: Hesketh out marsh west. Target Journal: Proceedings of the Institution of Civil Engineers, Sustainable Engineering 162(4):223228

Vasquez EA, Glenn EP, Guntenspergen GR, Brown JJ, Nelson SG (2006) Salt tolerance and osmotic adjustment of Spartina alterniflora (Poaceae) and the invasive M haplotype of Phragmites australis (Poaceae) along a salinity gradient. American Journal of Botany 93(12): 1784-1790

Walker LR (1991) Summary of the effects of Caribbean hurricanes on vegetation. Biotropica 23(4):442-447

Publisher's Note Springer Nature remains neutral with regard to jurisdictional claims in published maps and institutional affiliations. 